\title{
Lake Restoration and Management in a Climate Change Perspective: An Introduction
}

\author{
Erik Jeppesen 1,2,*, Martin Søndergaard ${ }^{1,2}$ and Zhengwen Liu 2,3,4 \\ 1 Department of Bioscience, Aarhus University, Vejlsøvej 25, 8600 Silkeborg, Denmark; ms@bios.au.dk \\ 2 Sino-Danish Centre for Education and Research, University of Chinese Academy of Sciences, \\ Beijing 100190, China; zliu@niglas.ac.cn \\ 3 Department of Ecology and Institute of Hydrobiology, Tropical and Subtropical Aquatic Ecological \\ Engineering Center of the Ministry of Education of China, Jinan University, Guangzhou 510630, China \\ 4 State Key Laboratory of Lake Science and Environment, Nanjing Institute of Geography \& Limnology, \\ Chinese Academy of Sciences, Nanjing 210008, China \\ * Correspondence: ej@bios.au.dk; Tel.: +45-30783165
}

Academic Editor: Athanasios Loukas

Received: 20 December 2016; Accepted: 3 February 2017; Published: 14 February 2017

\begin{abstract}
Lakes all around the globe are under severe pressure due to an increasing anthropogenic impact from a growing population in a more developed world. Accordingly, today, many lakes are highly eutrophic and suffer from severe blooms of often toxic cyanobacteria and may become even more eutrophic in the future unless strong lake management actions are taken. Recent research has further shown that global warming and subsequent changes in water use will further exacerbate the eutrophication process in lakes. There is therefore a growing demand for lake restoration and insight into sustainable lake management. The measures to be taken, however, depend on the climate and other local conditions. This special issue addresses lake restoration and management with special emphasis on the restoration of eutrophicated lakes within a climate change perspective. The papers included collectively highlight that the ongoing climate change affects lake water quality by (1) changes in external and internal nutrient loading; (2) higher frequency of extreme events (such as hurricanes); (3) temperature-induced changes in biota, biotic interactions; and (4) water level. Lower nutrient loading is therefore needed in a future warmer world to achieve the same ecological state as today. Several papers discuss lake restoration methods within a climate change perspective and show practical results, notably of various attempts of biomanipulation. Finally, some papers discuss the effects of other anthropogenic stressors and their interaction with climate.
\end{abstract}

Keywords: lakes; climate change; stressors; lake restoration; worldwide

\section{Introduction}

Freshwater ecosystems provide a wide range of ecosystem services, but changes in land use in populated areas have had significant detrimental influence on their ecological state. Consequently, man-made eutrophication still stands as the most important problem counteracting the presence of a favorable environmental state. In many countries worldwide, attempts have been made to restore the eutrophicated lakes by reducing the external nutrient loading. This has in many cases resulted in major improvements of lake ecological state, but a substantial delay in recovery has often been observed [1-3]. To speed up recovery after external loading reduction, a suite of physical-chemical and biological methods have been developed and used [4]. The results of these restorations have been variable and not always successful [4-8].

Recent studies have, furthermore, shown that it might be more difficult to combat eutrophication in a warmer world as warming in itself creates symptoms that are similar to eutrophication [9-12]. 
We can expect higher dominance of omnivorous fish, smaller fish, higher predation on zooplankton, less grazing on phytoplankton, higher dominance and blooming of cyanobacteria, higher internal phosphorus loading, and, in systems with more rain, higher external loading of nutrients [13].

This special issue of Water focuses on lake restoration and management with special emphasis on the restoration of eutrophicated lakes within a climate change perspective. Several papers also discuss the need for lower external loading targets in a warmer climate and describe relevant restoration methods and approaches under various climate conditions.

\section{Contributions}

\subsection{Temperate Climate Zone}

A two-decade (1989-2008) time series of lake phyto- and zooplankton, water characteristics, and climate in 17 Danish lakes was analyzed to elucidate the long-term changes and the effects of lake restoration efforts and climate warming [14]. The analyses of pair-wise correlations across time series revealed a strong synchrony in climatic variables, with a significant increase in air temperature and a weaker synchrony for the physico-chemical variables. Synchrony in lake chemistry and the taxonomic richness of the plankton groups and phytoplankton biomass was apparent, most pronounced for the lakes with a significant and strong negative trend in their total phosphorus (TP) concentrations. Phytoplankton biomass decreased and plankton richness increased in these lakes. A widespread significant positive trend in plankton richness was observed across all lakes coinciding with re-oligotrophication. The potential effect of climate on synchrony and long-term trends in lake chemistry and plankton was modest but is probably confounded by the more dominant effects of nutrient reduction.

Focusing on specific lakes, the climate effect may become more apparent. This was shown in an analysis of a comprehensive 23-year long data series from shallow Danish Lake Søbygård, which is in recovery after a major nutrient loading reduction [15]. Focus in this study was on changes in zooplankton. A shift in macrozooplankton from initial dominance of Daphnia spp. towards Bosmina spp. was found as well as a decline in the body size of copepods and an increase in the abundance of nauplii. These changes coincided with an increase in the abundance of small-sized fish as a result of rising water temperatures [7]. A cascading effect on phytoplankton was clearly evidenced by an enhanced zooplankton/phytoplankton biomass ratio and a decrease in chlorophyll $a / \mathrm{TP}$ and chlorophyll $a /$ total nitrogen ratios. The results indicate that climate warming, through changes in the size structure of the fish community, has major effects on zooplankton size structure. In this lake, the decline in zooplankton size did not prevent, but modulated, the positive cascading effect on phytoplankton obtained by the expected diminished fish biomass related to nutrient loading reduction.

Modeling results from the same lake support this conclusion. The ecological model PCLake was applied to Lake Søbygård and simulated multiple combinations of increasing temperatures $\left(0-6{ }^{\circ} \mathrm{C}\right)$ and reduced external nutrient loads $(0 \%-98 \%)$ with and without internal phosphorus loading [16]. The simulations revealed that nitrogen was the main limiting nutrient for primary production, reflecting ample phosphorus release from the sediment. The nutrient loading reduction scenarios projected increased diatom dominance accompanied by an increase in the zooplankton/phytoplankton biomass ratio. As in [15], a higher proportion of small fish and enhanced fish predation with increasing warming were revealed. The simulations generally showed phytoplankton to benefit from a warmer climate and the fraction of cyanobacteria to increase and that a higher external loading reduction is necessary in a future warmer world to maintain the present ecological state. By way of example, in a $6{ }^{\circ} \mathrm{C}$ warming scenario, the nutrient load reduction has to be as high as $60 \%$ to achieve summer chlorophyll $a$ concentrations similar to those of the baseline scenario with present-day temperatures.

The above as well as other studies of Danish lakes $[13,17,18]$ have collectively shown not only that it is possible to improve lake ecological state by reducing the external loading but also that the 
ongoing climate change requires a stronger reduction of external loading to achieve the target "good ecological status" stipulated in the EU Water Framework Directive.

To reinforce recovery after nutrient loading reduction, many different methods have been used $[4,6]$. Biomanipulation by fish removal has been applied in many shallow lakes in the temperate climate zone as a method to improve lake water quality, usually as a single intervention and usually followed by a few years' monitoring to record the effects. In many cases, the short-term effect has been substantial $[5,19,20]$. Longer-term studies have revealed that lakes often revert to the turbid state $[6,20]$. Repeated treatment has therefore been suggested [7]. In an article in this special issue [21], an analysis is presented of 30 years of chemical and biological data on shallow 16 ha Danish Lake Væng that has been biomanipulated twice with a 20-year interval by removing coarse fish, the second time due to unsatisfactory long-term results. After both biomanipulations, the lake shifted from a turbid, phytoplankton-dominated state to a clear water macrophyte-dominated state. Chlorophyll $a$ decreased substantially, and the coverage of submerged macrophytes, dominated by Elodea canadensis, increased from $<0.1 \%$ to $70 \%-80 \%$. The effects of the first and second biomanipulation lasting for at least eight years were similar and included a marked change in the internal nutrient cycling. Mean summer total phosphorus and nitrogen concentrations decreased by $40 \%-60 \%$. The future of the lake is, however, somewhat uncertain due to, for instance, an unexpectedly high phosphorus loading from groundwater. The authors provide further evidence that repeated fish removal might be a relevant management strategy to apply in shallow lakes with a relatively high external nutrient loading.

\subsection{Mediterranean and Subtropical Climate Zone}

Lakes in the Mediterranean climate zone experience strong variation in rainfall and are highly vulnerable to changes in climate, land cover, and antropogenically induced effects on water level and salinity [22]. Spatio-temporal changes were analyzed at the catchment scale of two connected lakes in Greece that have recently exhibited a dramatic loss of water volume for which climate change is potentially the main driver [23]. The results showed that almost $23 \%$ and $32 \%$ of the area of the two lakes were replaced by cultivations and reed beds from 1972 to 2011. Precipitation has shown a declining trend, leading to a decrease in water level and an increase in conductivity and chloride concentrations. The authors conclude that a combined effect of climate and human-induced land cover changes is likely responsible for the drastic environmental changes and call for implementation of effective restoration and mitigation measures. Spatio-temporal variation was also in focus in a study of large subtropical Lake Taihu [24] where in-lake variation in water quality was compared with the associated variation in external loading. Hierarchical cluster analysis grouped the data into two seasons and the 20 sampling sites into two groups based on similarities in river water quality characteristics. One group received more industrial and domestic pollution-related agricultural runoff than the other that was mainly influenced by a combination of point and non-point sources. Discriminant analysis was used to identify the most important variables contributing to the clustering and principal component analysis was used to identify potential pollution sources. The authors conclude that comprehensive analysis using multiple methods could be more effective for facilitating efficient management for the lake in the future.

Many subtropical and tropical lakes are located in tropical cyclone strike zones and experience high inter-seasonal and inter-annual variation in rainfall and runoff. Both factors strongly modulate sediment-water column interactions, which play a critical role for shallow lake nutrient cycling, water column irradiance characteristics, and cyanobacterial harmful algal bloom dynamics. Long-term (15 to 25 years) datasets on water quality and plankton were analyzed from three shallow lakes: Lakes Okeechobee and George (Florida, USA) and Lake Taihu (China) [25]. Okeechobee and Taihu have been impacted repeatedly by tropical cyclones, creating large amounts of runoff and sediment resuspension and consequent increases in dissolved nutrients in the water column. In both cases, when turbidity declined, major blooms of the toxic cyanobacteria Microcystis aeruginosa occurred over large areas of the lakes. In Lake George, periods of high rainfall resulted in high dissolved color, reduced irradiance, 
and increased water turnover rates, suppressing the blooms, whereas in dry periods with lower water color and water turnover rates, there were dense cyanobacteria blooms. Using an expert judgement approach, a suite of factors were identified that will determine how a particular shallow lake will respond to a future with global warming, flashier rainfall, prolonged droughts, and stronger tropical cyclones [25].

Eutrophication and climate variation also interact strongly in Mediterranean Turkish lakes, with implications also for their restoration. Twenty years of monitoring data from two interconnected Central Anatolian lakes, Lake Eymir and Lake Mogan, both of which have received sewage effluents and undergone restoration, were investigated [26]. In the restoration of eutrophic Lake Eymir, sewage effluent removal was first undertaken, and the lake was then biomanipulated twice. Lake Mogan, which only received a small amount of sewage that was diverted, served as a semi-control. Both lakes underwent alternating severe drought and wet periods. In Lake Eymir, biomanipulation led to a clear water state with an abundant macrophyte community. Following a prolonged drought period creating deteriorated water clarity, the plants disappeared again, however. A second biomanipulation was initiated in a drought period and was continued during the subsequent wet period. It resulted in decreased nutrient concentrations and clear water conditions, but without expansion of macrophytes. In contrast, during a period with drought and a low water level, shallow Lake Mogan experienced rapid expansion of macrophytes. Maintaining a good ecological state of lakes located in arid climates during drought periods appears to be a major challenge, especially seen in the light of the current climate change.

The role of external loading of phosphorus and nitrogen in the ecological status of lakes is subject to heated debate, but it seems evident that high nitrogen $(\mathrm{N})$ loading may contribute to recession of submerged macrophytes in eutrophic shallow lakes (e.g. [11,27]); yet, its influences vary depending on environmental conditions. In a study presented in this special issue [28], an investigation was undertaken of whether the effect of high $\mathrm{N}$ loading on Vallisneria natans growth in systems depended on the nutrient status of the sediment in subtropical lakes. Growth of $V$. natans was observed to decrease significantly with increasing $\mathrm{N}$ loading. In low nutrient sediment, the relative growth rate, leaf biomass, and root biomass decreased by $12 \%-23 \%$, respectively, but by as much as $33 \%-44 \%$ when using high nutrient sediment. The larger effect in nutrient-rich sediment was attributed to an observed higher shading of phytoplankton and excess nutrient accumulation in plant tissue. The results confirm the occurrence of a negative effect of increasing $\mathrm{N}$ loading on submerged plant growth in shallow nutrient-enriched lakes and further show that this effect is augmented when the plants grow in nutrient-rich sediment. The authors conclude that external $\mathrm{N}$ control may help protect or restore submerged macrophytes, in eutrophic lakes, especially when the sediment is enriched with nutrients and organic matter.

Artificial substrate may potentially be a useful tool to speed up recovery after nutrient loading reduction if macrophyte establishment is delayed. It may act as a daytime refuge for zooplankton enhancing the overall grazing on phytoplankton, which may improve water clarity and augment the growth potential of the submerged macrophytes [7]. How artificial substrate affects the competition between planktonic and benthic primary producers is not well-studied. A short-term outdoor mesocosm experiment was conducted [29] to test the hypothesis that the nutrient and light changes induced by exposed artificial substrate (polythene nets) would benefit the benthic algae and thus indirectly water clarity. It was found that the artificial substrate significantly reduced total nitrogen and phosphorus and phytoplankton biomass, while benthic algae biomass and water clarity increased. Artificial substrate may thus pave the way for a benthic- or a macrophyte-dominated system. Longer term and larger scale experiments are, however, needed before any firm conclusions can be drawn on the practical usability of the method.

As stated above, fish removal has been used to restore temperate lakes when external nutrient loading has been reduced, and positive effects on ecological state and water clarity have been recorded in many lakes. In warm lakes, however, enhanced top-down control by zooplankton is 
not to be expected as high recruitment of fish and dominance of small fish will prevent large-bodied zooplankton from becoming dominant $[7,28,30]$. Recently, transplantation of submerged macrophytes as a supplementary measure to fish removal has been applied to restore warm Chinese shallow lakes in order to compensate for the expected lack of increasing grazing control of phytoplankton after biomanipulation in warm lakes. These two measures combined have successfully shifted warm lakes to a clear water state [28], but little is known about the responses to restoration of key physico-chemical variables. An analysis was made of the seasonal variation in nutrient concentrations in two subtropical and one tropical biomanipulated shallow Chinese lake subjected to restoration [31]. In all lakes, a marked decline occurred in the concentrations of lake TN, TP, total suspended solids (TSS), and chlorophyll $a$, while the transparency (SD/WD ratio, i.e., Secchi depth-to-water depth ratio) increased. A clear water state was established, and TN, TP, chlorophyll $a$, and TSS concentrations in the three restored lakes decreased to $18 \%-58 \%$ compared with the references, while the transparency of the water increased substantially. To maintain the positive effects, continuous control of omnivorous and herbivorous fish biomass was recommended as the fish typically present in warm, shallow lakes partly consume submerged macrophytes.

It is debatable which fish should be removed or controlled when restoring (sub)tropical lakes by biomanipulation as some fish or some life stages of fish may benefit plant growth by removing periphyton. In many lakes in South-East Asia, also crucian carp (Carassius carassius) have been stocked to improve fishery. In a study included in this special issue [32], food web investigations using stable isotopes were combined with gut content analyses of the most dominant fish species to elucidate similarities and differences in food web structure between a restored, now clear water macrophyte-dominated basin (MDB) and an unrestored, turbid phytoplankton-dominated basin of Huizhou West Lake, a shallow tropical Chinese lake. The diet of the dominant fish species, crucian carp in MDB, consisted mainly of vegetal matter (macrophytes and periphyton) and zooplankton. This dual effect (consumption of macrophytes and zooplankton) may reduce the chances of maintaining the clear water state at the prevailing nutrient levels in the lake, and the authors conclude that regular removal of large crucian carp may be needed to maintain good ecological status.

\subsection{Effects of Other Stressors}

This special issue also includes effects of other types of anthropogenic activities. Changes in water level were analyzed over a 54-year long period in Dongting Lake (one of the largest lakes in China) [33]. In this lake, the water level has changed markedly due to a combined effect of climatic change and anthropogenic activities, not least the establishment of the Three Gorge Reservoir (TGR). Annual maximum, mean, and minimum lake water levels all increased from 1961 to 2014, but differentially, depending on climate and upstream activities. Discharge data and numerical modeling showed that the operation of TGR has substantially affected the inter-annual variation of the water level in Dongting, especially in the flood and dry seasons. The seasonal water level fluctuations have decreased markedly, and so has the probability of strong future drought and flood events in the lake.

Two fluvial gravel pit lakes called DLV Lake and BP Lake in the Meuse River valley were examined from 2003 to 2014 [34]. Water from the Meuse River is pumped into DLV Lake that is used for drinking water production. The authors found that the effects of river water infiltration on DLV Lake were (1) a change in lake water temperature; (2) an increase in nitrate concentration; (3) an increase in phosphate concentration; and (4) a decrease in sulfate concentration. Installed air blowers decreased $\mathrm{pH}$ in spring and increased summer $\mathrm{O}_{2}$. By contrast, decreasing nitrate and phosphate concentrations in BP Lake and Meuse River reflect a diminished use of fertilizers. This poses a challenge to lake managers to find the right balance between the reduction of eutrophication and the accumulation of nutrients and sulfate.

Results are presented of a multi-annual study of a small boreal humic lake of NW Russia [35]. A shallow and a deep site of the lake were regularly sampled for a range of chemical and biological parameters. Average multi-daily, summertime values of temperature, nutrients, and bacterioplankton 
concentrations in the epilimnion revealed that local pollution impacted the shallow site to a larger extent than the deep site. Organic phosphorus, nitrate, and lead were found to be the most efficient tracers of local anthropogenic pollution. According to the authors, the capacity of the lake's self-purification depends on the ratio of primary productivity to mineralization of organic matter. This ratio remained $>1$ during both winter and summer, which indicates that the lake has a high capacity to recover from inputs of allochthonous dissolved organic matter and local anthropogenic pollution.

Finally, the impact was assessed of rivers on the accumulation of heavy metals in bottom sediments of natural lakes comprised in postglacial river-lake systems [36]. The results obtained showed that a river flowing through a lake is a key factor determining the input/accumulation of the majority of the occurring fractions of heavy metals $(\mathrm{Zn}, \mathrm{Mn}, \mathrm{Cd}$, and Ni). The results suggest that lakes act as filters and contribute to the self-purification of water that flows through them. As a result, the content of most metals in lake sediments showed a decrease by approximately $75 \%$ between the upstream (inflow) and downstream (outflow) sections. The authors propose that stress on lake ecosystems can be reduced by temporarily removing pollutants such as toxic metals and depositing them around the delta.

\section{Conclusions}

This special issue highlights that lakes are affected by multiple stressors such as nutrients, allochthonous input of dissolved organic matter, human- and climate-induced changes in water level (due, for instance, to damming of rivers), and water infiltration and climate-induced changes in nutrient loading and temperature. Such changes pose big challenges for lake managers. Most papers in this current special issue focus on the effects of nutrient interactions with climate and how to restore eutrophicated lakes in different climate zones. Most past studies on the restoration of eutrophicated lakes have been conducted in the north temperate region, but in recent years more and more studies have been reported from other climate zones as well, which is further demonstrated in this special issue. It is evident that modified and alternative methods to those applied in the north temperate region are needed for warm lakes. It seems that combined methods (selected from an assembly of physical, chemical, and biological methods) may be more cost-effective and have longer-term effects than single approaches [7] and that the best combination may differ among climate zones. However, more research into this is needed before any firm conclusions can be drawn. A pre-requisite for successful restoration in all climate zones in the long term is a sufficient reduction of external nutrient loading, but the threshold for obtaining clear water conditions differs among climate zones and is likely lower in warm than in cold lakes. Definition of these thresholds is a remaining challenge warranting further study. A final subject highlighted in this special issue is the challenges that lake managers are facing when multi-stressors and climate change interact, an interesting and important topic for elucidation

Acknowledgments: The writing of this special issue was supported by Danish Centre for Environment and Energy, the MARS project (Managing Aquatic ecosystems and water Resources under multiple Stress) funded under the 7th EU Framework Programme, Theme 6 (Environment including Climate Change), Contract No. 603378 (http:/ / www.mars-project.eu), CLEAR (a Villum Kann Rasmussen Centre of Excellence project), PROGNOS (Predicting in-lake RespOnses to chanGe using Near real time mOdelS-Water Joint Programme Initiative), and AQUACOSM (Network of Leading European AQUAtic MesoCOSM Facilities Connecting Mountains to Oceans from the Arctic to the Mediterranean).

Author Contributions: Erik Jeppesen wrote the first draft of the summary on which Martin Søndergaard and Zhengwen Liu commented.

Conflicts of Interest: The authors declare no conflict of interest.

\section{References}

1. Sas, H. (Ed.) Lake Restoration by Reduction of Nutrient Loading: Expectation, Experiences, Extrapolation; Academia Verlag Richardz GmbH.: St Augustin, Germany, 1989. 
2. Jeppesen, E.; Søndergaard, M.; Jensen, J.P.; Havens, K.; Anneville, O.; Carvalho, L.; Coveney, M.F.M.; Deneke, R.; Dokulil, M.; Foy, B.; et al. Lake responses to reduced nutrient loading-An analysis of contemporary long-term data from 35 case studies. Freshw. Biol. 2015, 50, 1747-1771. [CrossRef]

3. Søndergaard, M.; Bjerring, R.; Jeppesen, E. Persistent internal phosphorus loading in shallow eutrophic lakes. Hydrobiologia 2013, 710, 95-107. [CrossRef]

4. Cooke, G.D.; Welch, E.B.; Peterson, S.A.; Nicholson, S.A. Restoration and Management of Lakes and Reservoirs; CRC Press: Boca Raton, FL, USA, 2015.

5. Hansson, L.-A.; Annadotter, H.; Bergman, E.; Hamrin, S.F.; Jeppesen, E.; Kairesalo, T.; Luokkanen, E.; Nilsson, P.-Å.; Søndergaard, M.; Strand, J. Biomanipulation as an application of food-chain theory: Constraints, synthesis, and recommendations for temperate lakes. Ecosystems 1998, 1, 558-574. [CrossRef]

6. Søndergaard, M.; Jeppesen, E.; Lauridsen, T.L.; Skov, C.; Van Nes, E.H.; Roijackers, R.; Lammens, E.; Portielje, R. Lake restoration: Successes, failures and long-term effects. J. Appl. Ecol. 2007, 44, 1095-1105. [CrossRef]

7. Jeppesen, E.; Søndergaard, M.; Lauridsen, T.L.; Davidson, T.A.; Liu, Z.; Mazzeo, N.; Trochine, C.; Özkan, K.; Jensen, H.S.; Trolle, D.; et al. Biomanipulation as a restoration tool to combat eutrophication: Recent advances and future challenges. Adv. Ecol. Res. 2012, 47, 411-487.

8. Lürling, M.; Mackay, E.B.; Reitzel, K.; Spears, B.M. Editorial-A critical perspective on geo-engineering for eutrophication management in lakes. Water Res. 2016, 97, 1-10.

9. Jeppesen, E.; Kronvang, B.; Meerhoff, M.; Søndergaard, M.; Hansen, K.M.; Andersen, H.E.; Lauridsen, T.L.; Beklioglu, M.; Özen, A.; Olesen, J.E. Climate change effects on runoff, catchment phosphorus loading and lake ecological state, and potential adaptations. J. Environ. Qual. 2013, 38, 1930-1941. [CrossRef] [PubMed]

10. Jeppesen, E.; Kronvang, B.; Olesen, J.E.; Audet, J.; Søndergaard, M.; Hoffmann, C.C.; Andersen, H.E.; Lauridsen, T.L.; Liboriussen, L.; Larsen, S.E.; et al. Climate change effects on nitrogen loading from cultivated catchments in Europe: Implications for nitrogen retention, ecological state of lakes and adaptation. Hydrobiologia 2011, 663, 1-21. [CrossRef]

11. Moss, B.; Kosten, S.; Meerhoff, M.; Battarbee, R.W.; Jeppesen, E.; Mazzeo, N.; Havens, K.; Lacerot, G.; Liu, Z.; De Meester, L.; et al. Allied attack: Climate change and eutrophication. Inland Waters 2011, 1, 101-105. [CrossRef]

12. Kosten, S.; Huszar, V.L.M.; Bécares, E.; Costa, L.S.; van Donk, E.; Hansson, L.-A.; Jeppesen, E.; Kruk, C.; Lacerot, G.; Mazzeo, N.; et al. Warmer climate boosts cyanobacterial dominance in lakes. Glob. Chang. Biol. 2012, 18, 118-126. [CrossRef]

13. Jeppesen, E.; Moss, B.; Bennion, H.; Carvalho, L.; DeMeester, L.; Friberg, N.; Gessner, M.O.; Lauridsen, T.L.; May, L.; Meerhoff, M.; et al. Interaction of climate change and eutrophication. In Climate Change Impacts on Freshwater Ecosystems; Kernan, M., Battarbee, R., Moss, B., Eds.; Blackwell Publishing Ltd.: Oxford, UK, 2010; pp. 119-151.

14. Özkan, K.; Jeppesen, E.; Davidson, T.A.; Bjerring, R.; Johansson, L.S.; Søndergaard, M.; Lauridsen, T.L.; Svenning, J.-C. Long-term trends and synchrony in lake plankton and abiotic characteristics driven by recovery from eutrophication and climate across 17 Danish Lakes. Water 2016, 8, 427. [CrossRef]

15. Gutierrez, M.F.; Devercelli, M.; Brucet, S.; Lauridsen, T.L.; Søndergaard, M.; Jeppesen, E. Is recovery of large-bodied zooplankton after nutrient loading reduction hampered by climate warming? A long-term study of shallow hypertrophic Lake Søbygaard, Denmark. Water 2016, 8, 341.

16. Rolighed, J.; Jeppesen, E.; Søndergaard, M.; Bjerring, R.; Janse, J.H.; Mooij, W.M.; Trolle, D. Climate change makes recovery from eutrophication more difficult in shallow Danish Lake Søbygaard. Water 2016, 8, 459. [CrossRef]

17. Nielsen, A.; Trolle, D.; Bjerring, R.; Søndergaard, M.; Olesen, J.E.; Janse, J.H.; Mooij, W.M.; Jeppesen, E. Effects of climate and nutrient load on the water quality of shallow lakes assessed through ensemble runs by PCLake. Ecol. Appl. 2014, 24, 1926-1944. [CrossRef]

18. Trolle, D.; Nielsen, A.; Rolighed, J.; Thodsen, H.; Andersen, H.E.; Karlsson, I.B.; Refsgaard, J.C.; Olesen, J.E.; Bolding, K.; Kronvang, B.; et al. Projecting the future ecological state of lakes in a 6 degree warming scenario. Clim. Res. 2015, 64, 55-72. [CrossRef]

19. Gulati, R.D.; Pires, L.M.D.; Van Donk, E. Lake restoration studies: Failures, bottlenecks and prospects of new ecotechnological measures. Limnologica 2008, 38, 233-247. [CrossRef] 
20. Søndergaard, M.; Liboriussen, L.; Pedersen, A.R.; Jeppesen, E. Lake restoration by fish removal: Short and long-term effects in 36 Danish lakes. Ecosystems 2008, 11, 1291-1305. [CrossRef]

21. Søndergaard, M.; Lauridsen, T.L.; Johansson, L.S.; Jeppesen, E. Repeated fish removal to restore lakes: Case study Lake Væng, Denmark-Two biomanipulations during 30 years of monitoring. Water 2017, 9, 43. [CrossRef]

22. Jeppesen, E.; Brucet, S.; Naselli-Flores, L.; Papastergiadou, E.; Stefanidis, K.; Nõges, T.; Nõges, P.; Attayde, J.L.; Zohary, T.; Coppens, J.; et al. Ecological impacts of global warming and water abstraction on lakes and reservoirs due to changes in water level and salinity. Hydrobiologia 2015, 570, 201-227. [CrossRef]

23. Stefanidis, K.; Kostara, A.; Papastergiado, E. Implications of human activities, land use changes and climate variability in Mediterranean lakes of Greece. Water 2016, 8, 483. [CrossRef]

24. Chen, Y.; Zhao, K.; Wu, Y.; Gao, S.; Cao, W.; Bo, Y.; Shang, Z.; Wu, J.; Zhou, F. Spatio-temporal patterns and source identification of water pollution in Lake Taihu (China). Water 2016, 8, 86. [CrossRef]

25. Havens, K.; Paerl, H.; Philips, E.; Zhu, M.; Beaver, J.; Srifa, A. Extreme weather events and climate variability provide a lens to how shallow lakes may respond to climate change. Water 2016, 8, 229. [CrossRef]

26. Beklioğlu, M.; Bucak, T.; Coppens, J.; Bezirci, G.; Tavşanoğlu, Ü.N.; Çakıroğlu, A.İ.; Levi, E.E.; Erdoğan, Ş.; Filiz, N.; Özkan, K.; et al. Restoration of eutrophic lakes in drought stricken Mediterranean: A system of eutrophic and control lakes. Water 2017, in press.

27. Olsen, S.; Jeppesen, E.; Moss, B.; Özkan, K.; Beklioglu, M.; Feuchtmayr, H.; González Sagrario, M.; Li, W.; Larsen, S.E.; Søndergaard, M. Effect of nitrogen loading, salinity, temperature and water level on the nitrogen retention capacity in lakes: An experimental approach. Freshw. Biol. 2015, 60, 642-662.

28. Gu, J.; Xu, Z.; Ning, X.; Jin, H.; He, H.; Yu, J.; Jeppesen, E.; Li, K. Response of eelgrass (Vallisneria natans) to increasing nitrogen loading is depending on sediment nutrient characteristics. Water 2016, 8, 563. [CrossRef]

29. He, H.; Luo, X.; Jin, H.; Gu, J.; Jeppesen, E.; Liu, Z.; Li, K. Effects of exposed artificial substrate on the competition between phytoplankton and benthic algae: Implications for shallow lake restoration. Water 2017, 9, 24. [CrossRef]

30. Liu, Z.W.; Zhong, P.; Zhang, X.; Ning, J.; Larsen, S.E.; Jeppesen, E. Successful restoration of a tropical shallow eutrophic lake: Strong bottom-up but weak top-down effects recorded. In Australia-China Wetland Network Research Partnership, Proceedings of the Symposium on Australia-China Wetland Network Research Partnership, Nanjing, China, 23-28 March 2014; Kattel, G., Ed.; Collaborative Research Network, Federation University Australia: Mt. Helen, Australia, 2014; pp. 78-86.

31. Yu, J.; Liu, Z.; Li, K.; Chen, F.; Guan, B.; Hu, Y.; Zhong, P.; Tang, Y.; Zhao, X.; He, H.; et al. Restoration of shallow lakes in subtropical and tropical China: Response of nutrients to biomanipulation by fish removal and submerged plant transplantation. Water 2016, 8, 438. [CrossRef]

32. Gao, J.; Zhong, P.; Ning, J.; Liu, Z.; Jeppesen, E. Herbivory of omnivorous fish shapes the food web structure of a Chinese tropical eutrophic lake: Evidence from stable isotope and fish gut content analyses. Water 2017, 9, 69. [CrossRef]

33. Han, Q.; Zhang, S.; Huang, G.; Zhang, R. Analysis of long-term water level variation in Dongting Lake, China. Water 2016, 8, 306. [CrossRef]

34. Mollema, P.N.; Antonellini, M.; Hubeek, A. Long term hydrochemical trend analysis of two fluvial gravel pit lakes (The Netherlands) with different post-excavation uses: Implications for eutrophication. Water 2016, 8 , 409. [CrossRef]

35. Shirokova, L.; Vorobyeva, T.; Zabelina, S.; Klimov, S.; Moreva, O.; Chupakov, A.; Makhnovitch, N.; Gogolitsyn, V.; Sobko, E.; Shorina, N.; et al. Small boreal lake ecosystem evolution under the influence of natural and anthropogenic factors: Results of multidisciplinary long-term study. Water 2016, 8, 316. [CrossRef]

36. Kuriata-Potasznik, A.; Szymczyk, S.; Glińska-Lewczuk, K.; Cymes, I. Heavy metal contamination in the surface layer of bottom sediments in a flow-through lake: A case study of Lake Symsar in northern Poland. Water 2016, 8, 358. [CrossRef]

(C) 2017 by the authors; licensee MDPI, Basel, Switzerland. This article is an open access article distributed under the terms and conditions of the Creative Commons Attribution (CC BY) license (http:/ / creativecommons.org/licenses/by/4.0/). 